
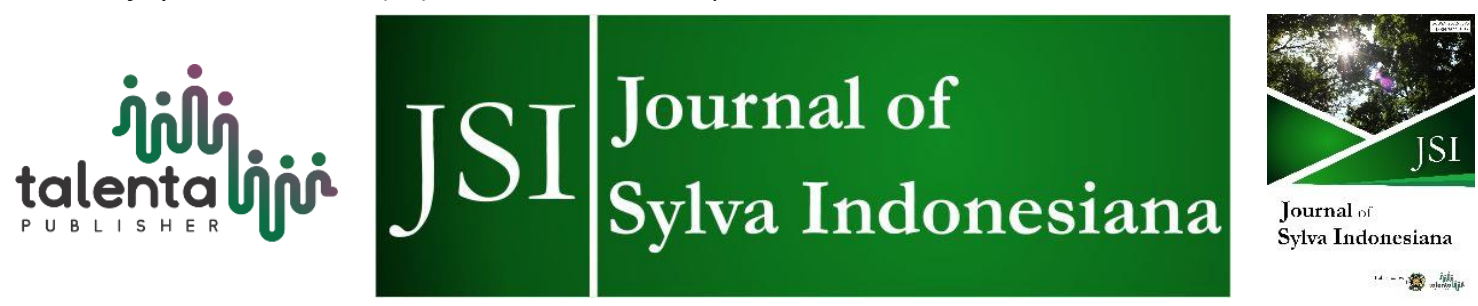

\title{
The Gender Role in Agroforestry Management in Sungai Langka Village, Gedong Tataan District, Pesawaran Regency, Lampung Province
}

\author{
Septo Widodo Pasaribu', Hari Kaskoyo ${ }^{2}$, Rahmat Safe ${ }^{\prime 3}$ \\ 1,2,3 Forestry Department, Faculty of Agricultural, Lampung University, Lampung, Indonesia
}

\begin{abstract}
Researchers have been developing agroforestry for community welfare. The management of agroforestry is an inseparable from active role of community and closely related to the role of gender. This study aims to determine the role of gender in management of agroforestry on private land and forests land. Sampling was carried out using simple random sampling method. The data was collected using a questionnaire interview, then tabulated and analyzed using Harvard's Gender Model analysis. The residents of Sungai Langka relied on agriculture with an agroforestry system implemented on their private lands and on Tahura Wan Abdul Rachman area. The residents of Sungai Langka Village practiced a complex agroforestry system including land preparation, planting, plant maintaining, harvesting, transporting, post-harvesting, and marketing. The results showed that cultivation activities and transportation were $100 \%$ dominated by men. Men tended to perform land preparation $(76.74 \%)$ and planting $(93.02 \%)$, while women tended to carry out postharvesting $(93.02 \%)$ and marketing $(93.02 \%)$.
\end{abstract}

Keyword: Agroforestry, Gender, Gender Roles

Received 27 April 2019 | Revised 09 July 2019 | Accepted 15 August 2019

\section{Introduction}

Agroforestry is a land management system which combines agricultural production, including fruit trees and or livestock with forestry plants [1]. Some experts stated that agroforestry systems provide many ecological, economic, and social benefits [2]-[4]. The management of agroforestry is an inseparable and closely related to the role of genders in community. Men and women had differences both socially and biologically. Social differences between men and women called gender [5]. Gender generates differences of roles, duties, and responsibilities between men and women which is called the gender

\footnotetext{
*Corresponding author at: Lampung University, Jl. Prof. Dr. Soemantri Brojonegoro No. 1, Gedung Meneng, Bandar Lampung, 35145, Indonesia

E-mail address: septowidodo1@gmail.com
} 
roles [6]. Gender roles have been applied in all aspects of life, one of that is gender roles in natural resource management.

In African countries, gender divides men to manage natural resources while women manage households [7]. On the contrary, [8] study revealed that Ugandan women also contributed themselves to help men for managing natural resources. The gender roles were also implemented in agroforestry management. In [9]-[11] studies, they stated that both men and women share roles in agroforestry management according to their respective abilities.

Studies about gender roles in agroforestry management to private land, community forest, and state forest have already been conducted. Furthermore [9] observed the gender studies in management of clan and community forests while [10] focused on gender analysis in management of agroforestry; case studies in Pangalengan PLN Area in Bandung and [11] study on gender analysis in community forest management activities. The harvards model gender analysis method is one of methods the gender analysis that is often used but research on management of agroforestry, especially on private land and state forest, is still limited. Therefore, study of men and women activities on agroforestry management in private land and state forest is important.

\section{Materials and Method}

The research was carried out in June 2018 for one month in Sungai Langka Village, Gedong Tataan Subdistrict, Pesawaran District. The object of this study was the people of the Sungai Langka village who owned agroforestry land that was as many as 833 households based on the information from village head and village profile. The sampling method used in this study was Simple Random Sampling. The number of respondents was obtained using Slovin formula with $15 \%$ error limit. According to [12], if a population consists of more than 100 individuals the $15 \%$ error limit can be applied. The determination of sample size was obtained using Slovin formula:

$$
\mathrm{n}=\frac{\mathrm{N}}{\mathrm{N}(\mathrm{e})^{2}+1}=\frac{833}{833(15 \%)^{2}+1}=43
$$

\section{Description:}

$\mathrm{n}=$ respondent number

$\mathrm{N}=$ the number of households that have agroforestry land in Sungai Langka Village

$\mathrm{e}=$ error limit $15 \%$

$1=$ constant number

The unit of analysis used was a household consisting of 43 husbands and wives. 
Collected data consisted of (1) primary data of the respondent's identity (name, gender, age) and information. Also including their gender roles on agroforestry activities e.g. land preparation, planting, cultivating, harvesting, transporting, post-harvesting, and marketing; and (2) secondary data regarding studies from gender-related literature. Primary data obtained using observation and interview, while secondary data obtained using literature reviews.

Data related to agroforestry management activities in Sungai Langka Village were analyzed qualitatively. Processing data on gender roles in agroforestry management in Sungai Langka Village was presented in the form of data tabulation. The results were analyzed using gender analysis of Harvard model. According to [13], Harvard model analysis technique consisted of a matrix by collecting data at micro-level (community and household). The data included of productive, reproductive, and social activities data based on sex, data on details of what resources men and women controlled to carry out their activities, and factors that influenced of labor division based on gender. In this study, Harvard model analysis technique was used to identify activities carried out by farmers in a relevant manner and answer questions: who did what, therefore they could know what roles that men and women did in agroforestry management activities.

\section{Results And Discussion}

\subsection{Management of Agroforestry in Sungai Langka Village}

Sungai Langka Village is one of villages directly adjacent to the Wan Abdul Rachman Forest Park (also known as Tahura WAR). Tahura WAR is a state forest area in Lampung Province which is expected to function as development support in forestry, agriculture, plantation, and livestock sectors [14]. According to [15], Tahura WAR has a management block, one of which is utilization block. Land management in utilization blocks is carried out using an agroforestry management system. According to [16], agroforestry systems in Indonesia were classified into two namely simple agroforestry systems and complex agroforestry systems. Based on observations, farmers planted several types of forest plants with agricultural crops in one field. It means that they were implemented of complex agroforestry systems. This system was applied by farmers both on state forests land and on land owned by farmers. The agroforestry management activities carried out by farmers both on state forests land and on owned land were similar which included pre-harvest activities (land preparation, planting, plant maintaining, harvesting) and post-harvest activities (post-harvesting and marketing).

Land preparation carried out by farmers both on private land and on state forests land was almost same, except that in state forest land which was done once due to maintaining Tahura WAR as a nature conservation area. In private lands, land preparation activities can be conducted repeatedly. The activities included land clearing, land processing, mounding, and trenching, all carried out before the rainy season. Farmers planted several types of plants by combining forestry trees and agricultural crops. 
Forestry plants chosen by farmers were Multi-Purpose Tree Species (MPTS) including durian, stink bean, clove, and nutmeg. The main crops planted by farmers were ginger, long bean, chili, banana, and cacao. These plants planted by farmers in stages, starting from ginger to canopied-MPTS plants.

Planting activity was conducted at the beginning of rainy season with similar planting method on both private land and state forest. The interviews revealed that farmers learned from others experiences regarding successful plant species and planting patterns and implemented of knowledge on their own land. They also received knowledge from other sources, such as from Ministry of Agriculture and Universities.

The plant maintaining activities carried out by farmers were weeding, pruning, and fertilizing. Weeding was carried out on ginger, peanut, chili, and banana plants while pruning was conducted by cutting of young shoots on cocoa branches. According to the interviews result, cocoa pruning would optimize sunlight received by trees, thus productivity could be increased. This was in line with statement of [17] who stated that to achieve efficiency in utilizing sunlight, pruning was needed, therefore that plants are able to achieve high productivity. Pruning did not apply on MPTS plants as they encouraged to growth naturally. The next step of cultivation, fertilizing, was carried out on ginger, peanut, chili, and cocoa. According to [18], fertilizing is done to retain and repair soil's fertility, thus the soil productivity is increased and yield is optimized.

In Sungai Langka Village, most farmers of private lands preferred chemical fertilizer (urea, $N P K, K C L$ ) as they were able to apply repeatedly. Those who did not have enough money chose manure processed from goat waste over chemical fertilizer, or combination between the two. Farmers of state forests fully utilized of manure because it was less harmful to the environment. For a cocoa tree, they had to apply a sack of manure or $0.5 \mathrm{~kg}$ chemical fertilizer.

Harvesting by farmers in Sungai Langka Village was carried out gradually according to the planting period. This was in line with the study result of [19], which declared that farmers did the harvesting process by harvesting agroforestry products in stages according to the time of planting. The first harvested crop was peanut, at the age of 100 days from planting time. Gingers were planted at the end of the dry season and harvested 10 months later. Both crops were harvested by pulling the whole plant. A year after planting, chillis were picked out. Bananas, which planted on rainy season with cocoa, being harvested after chili season ended. Banana harvesting was over by the time when the cocoa pods were started to grow.

Three years after planting, cocoa pods were harvested twice a year using the bladed spear. Cloves were picked and transported using two-wheeled vehicles due to narrow and inclined terrain condition. Farmer transport crops were used a rickshaw or three-wheeled vehicles to adjust the conditions of the road 
contour and it allowed them to transport more yields [20]. Almost all farmers in Sungai Langka Village transported their yields by themselves, but those who wealthier preferred to pay IDR 15,000 to transporters.

Farmers on both private land and state forest carried out post-harvest activities such as cleaning of ginger, peanuts separating, stem-picking and drying of cloves, cocoa beans extracting and drying. Some plants such as banana, stink bean, durian, and nutmeg were not post-harvested because the yields were sold directly to wholesalers in bulk while chili, peanuts, and ginger were sold to the market. Banana, stink bean, durian, and nutmeg were sold in bulk while cocoa and cloves were sold in retails and picked up by middlemen at the farmer's houses. According to [21], most farmers sold cocoa to collectors in the village.

\subsection{Gender Role on Agroforestry Management}

The division of roles between women and men was a manifestation of gender roles. Based on the results of the research that has been done, women did not only take part in home chores; some respondent households involved women in several agroforestry management activities. Data from research results are presented in Figure 1.

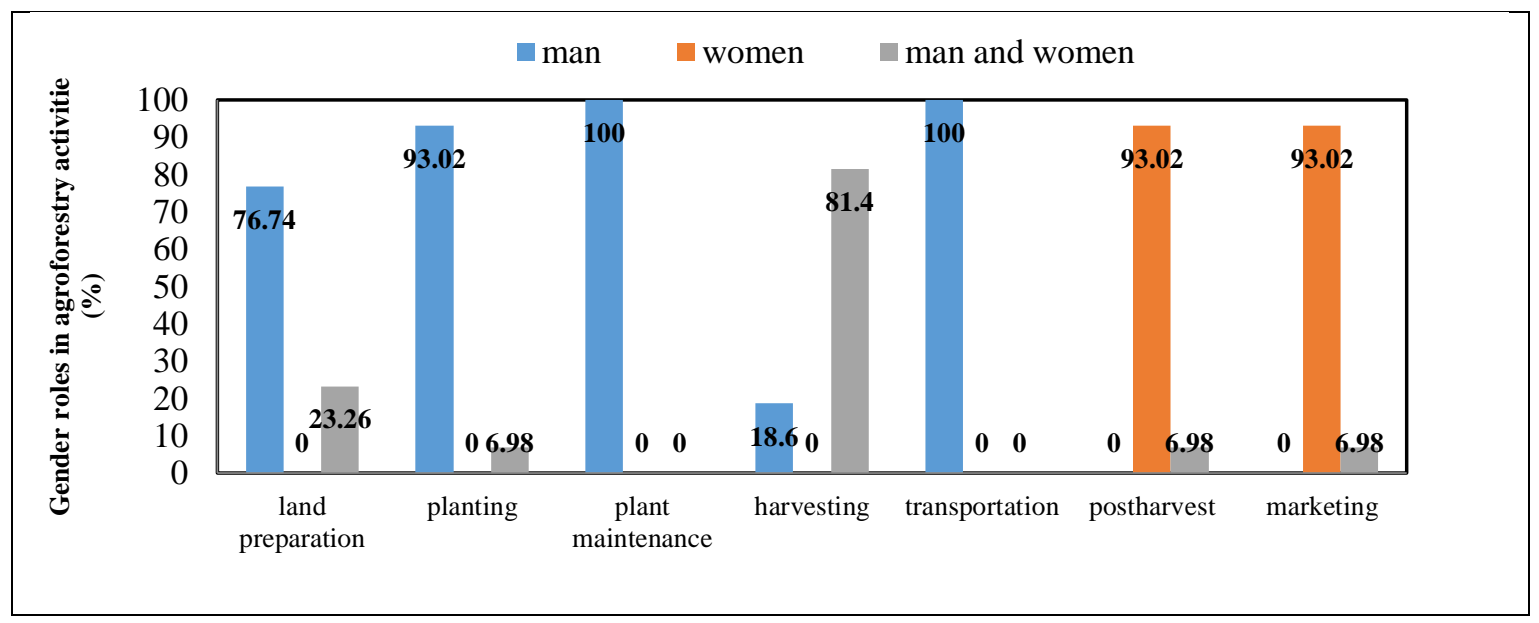

Figure 1 The gender roles in agroforestry management activities of farmer households in Sungai Langka Village

The study revealed that men dominating agroforestry management activities due to their responsibility to earn a living for their families. This was in line with the results of [11] who studied Gender Analysis in Community Forest Management Activities about men having a greater outpouring of work time than women in community forest management activities due to their bigger responsibility to earn a living for their families. Agroforestry management activities tended to be carried out by men in the respondent household, including land preparation (76.74\%), planting (93.02\%), plant maintenance (100\%), and transportation (100\%). Based on the results of interviews, land preparation, planting, plant maintenance, 
and transportation activities were classified as heavy work and require a large amount of labor. For this reason, it was more suitable carried out by men.

Some respondent of households allowed women to participate in agroforestry management activities in accordance with their abilities to ease of workload of their husbands. Women were willing to help men to work according to their abilities [22]. It was proven by their activities on land preparation (23.26\%), planting $(6.98 \%)$, harvesting (81.40\%), post-harvesting (6.98\%), and marketing (6.98\%) in order to help their husband's workload. According to [23] who stated in her study, the role of rural women in increasing household income, that women helped husbands doing the work of planting, maintaining plants, and harvesting on their farms.

Women were involved in land clearing activities such as cutting down shrubs and collecting of wastes to the side of the road. They were not permitted to do land cultivation and making trenches and ridges. According to [24] who study of land preparation carried out by Dani tribal farmers in the Baliem Valley, they explained that men have responsibility to open a new area, make fences and beds while women were in charge of inserting seeds into planting holes. A study related to gender analysis in management of agroforestry located in PLN Pangalengan Area in Bandung stated that a small number of women helped in planting activities such as putting up stakes and planting [10].

Almost all respondent households allowed women to carry out harvesting activities. Based on the result of interviews, harvesting were classified for mild activities, therefore women were being involved in processes. According to [10], women were only involved in light activities such as collecting ginger, peanut, cocoa, and clove yields. However, considered for being more diligent than men, women were in full charge on chili harvesting. Harvesting activities carried out by men assisted by women are presented in Figure 2.

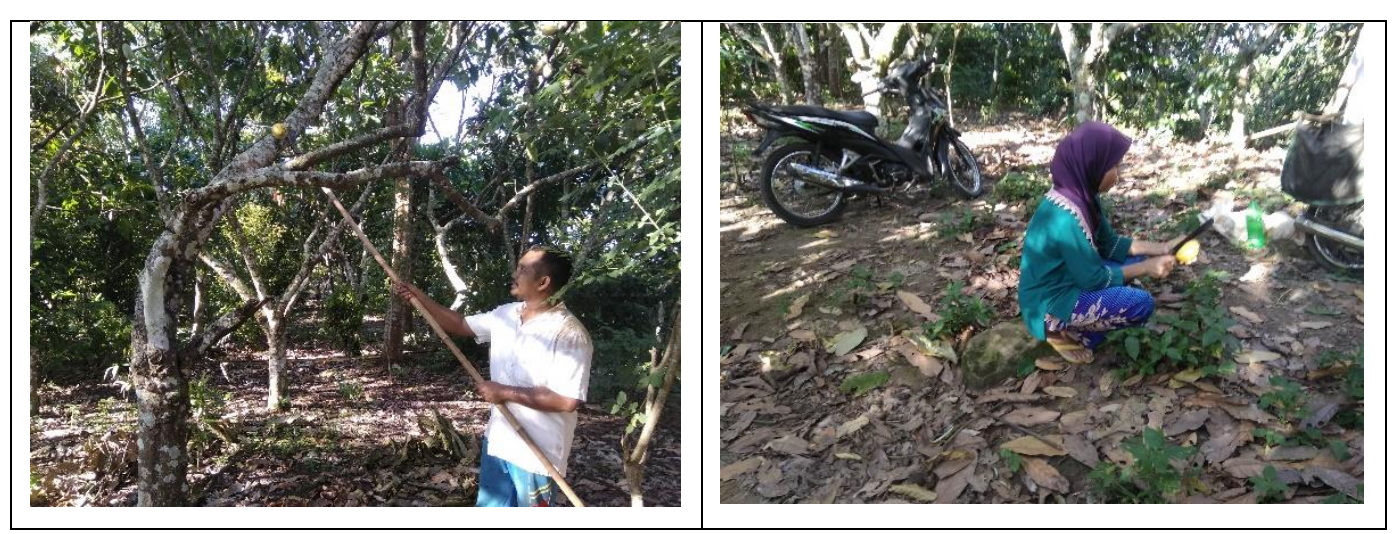

Figure 2 Men and women collaborating in cocoa harvesting 
The agroforestry management activities that dominated by women were post-harvesting and marketing, indicated by their high percentage (93.02\%). The interviews revealed that these activities were suitable for women because can be done while doing home chores such as cooking, cleaning the house, and taking care of children. The post-harvesting activities carried out by women in-between of doing home chores were cleaning the ginger, peanuts separating, stem picking, and drying of cloves, cocoa beans extracting and drying. This was in line with the results of [25] regarding the analysis of women role in agriculture at Rasau Jaya District, Kuburaya Regency. The results of the study showed that amount of time contribution that women gave to post-harvest and marketing activities was $55.22 \%$ and $52.97 \%$, respectively. The marketing activities carried out by women while doing home chores were selling the yields to local collectors who came to their houses. Women's direct involvements were acceptable as long as they were not abandoned their chore activities [25].

\section{Conclusion}

According to the results of the study, it was concluded that men were dominating in plant maintenance activities (100\%) and transportation (100\%). The agroforestry management activities that tended to carry out by men were land preparation $(76.74 \%)$ and planting $(93.02 \%)$, while women tended to carry out post-harvest activities (93.02\%) and marketing (93.02\%).

\section{REFERENCES}

[1] G. Senoaji, "Land Management with Agroforestry System by Baduy Community in South Banten," J. Bumi Lestari, vol. 12, no. 2, pp. 283 - 293. 2012.

[2] H. Kaskoyo, A.J. Mohammed, and M. Inoue, "Present State of Community Forest) Program in A Protection Forest and Its Challenges: Case Study in Lampung Province, Indonesia," J. of Forest Science, vol. 30, no. 1, pp.15-29. 2014.

[3] R. Qurniati, I.G. Febryano, and D. Zulfian, "How Trust Influence Social Capital to Support Collective Action in Agroforestry Development?," J. Biodiversitas, vol. 18, no. 3, pp. 1201-1206. 2017.

[4] R. Safe'i, H. Erly, C. Wulandari, and H. Kaskoyo, "Analysis of the Diversity of Tree Types as One of the Indicators of Forest Conservation Health," J. Perennial, vol. 14, no. 2, pp. 32-36. 2018.

[5] G. Wandi, "Reconstruction of Masculinity: Revealing the Role of Men in the Struggle of Gender Equality," J. Kafaah, vol. 5, no. 2, pp. 239-255. 2015.

[6] C. Manfre and D. Rubin, Integrating Gender into Forestry Research: A Guide for CIFOR Scientists and Programme Administrators, CIFOR, Bogor, p. 79, 2012.

[7] C. Perez, E.M. Jones, P.C. Kristjanson, D.L. Cramer, P. K. Thornton, W. Forch, and C. Barahona, "How Resilient are Farming Households and Communities to A Changing Climate in Africa? A Gender-based Perspective," J. Global Environmental Change, no. 34, pp. 95-107. 2015.

[8] A. P. Delaocampos, K. A. Covarrubias, and A. P. Patron, "How Does the Choice of the Gender Indicator Affect the Analysis of Gender Differences in Agricultural Productivity? Evidence from Uganda," J. World Development, no. 77, pp. 17-33. 2016.

[9] D. Sinaga, "Gender Assessment of Agroforestry Management in Belalau and Batu Ketulis Districts, West Lampung Regency," Essay, University of Lampung, Lampung, 2011.

[10] S.D. Ratnapuri, "Gender Analysis in Agroforestry Management," Essay, Bogor Agricultural Institute, Bogor, 2011. 
[11] M. Suwardi, "Gender Analysis in Community Forest Management Activities and Community Forest Contribution to Household Income," Essay, Bogor Agricultural Institute, Bogor, 2010.

[12] S. Arikunto, Research Procedure; A Practice Approach, Rineka Cipta, Jakarta, 2002.

[13] Ministry of Women's Empowerment, BKKBN, and UNFPA, Potpourri: Guides and Learning Materials Gender Mainstreaming Training in National Development, Ministry of Women's Empowerment, Jakarta, 2005.

[14] R. R. Syofiandi, R. Hilmanto, and S. Herwanti, "Analysis of Farmer Agroforestry Income and Welfare in Sumber Agung Sub-District Kemiling Sub-District, Bandar Lampung City," J. Sylva Lestari, vol. 4, no. 2, pp. 7-26. 2016.

[15] S. Tiurmasari, R. Hilmanto, and S. Herwanti, "Vegetation Analysis and Community Welfare Levels of Agroforestry Managers in Sumber Agung Village, Kemiling District, Bandar Lampung," J. Sylva Lestari, vol. 4, no. 3, pp. 71-82. 2016.

[16] H. De Foresta and G. Michon, "The Agroforest Alternative to Imperata Grasslands: when Smallholder Agriculture and Forestry Reach Sustainability," J. Agroforestry Systems, no. 36, pp. 105-120. 2000.

[17] A. A. Prawoto, "The Effect of Pangkasan on the Form of Cocoa Plants That Set the Plagiotropic Branches Against Growth and Fruit Results," J. Pelita Perkebunan, vol. 12, no. 3, pp. 119-126. 2008.

[18] V. F. Sianturi and A. Wachjar, "Management of Trimming of Arabica (Coffea arabica L.) Coffee Plants in Blawan Gardens, Bondowoso, East Java," J. Buletin Agrohorti, vol. 4, no. 3, pp. 266-275. 2016.

[19] R. Kader, H. D. Walangitan, S. P. Ratag, and M. Y. Sumakud, "Farming Income Patterns of Agroforestry Based on Coconut (Cocos nucifera) and Taro (Colocasia esculenta L) in Klabat Village, North Minahasa Regency,” J. Cocos, vol. 7, no. 5, pp. 10-16. 2016.

[20] O. Kristriandiny and S. Susanto, "Cultivation of White Dragon Fruit (Hylocereus undatus) in Sleman, Yogyakarta: Harvest and Postharvest," J. Agrohorti Bulletin, vol. 4, no. 1, pp. 18. 2017.

[21] I. Ali, "Analysis of Cocoa Production and Marketing in Tunong Village, Keumala District, Pidie District," J. Agrisep, vol. 14, no. 2, pp. 1-11. 2013.

[22] R. Elizabeth, "Women's Empowerment Supports Gender Mainstreaming Strategies in Rural Agricultural Development Policies," Agro Economic Research Forum, vol. 25, no. 2, pp. 126-135. 2007.

[23] I. M. Hanum, R. Qurniati, and S. Herwanti, "The Role of Rural Women in Increasing Household Income," Sylva Lestari Journal, vol. 6, no. 3, pp. 36-45. 2018.

[24] E. N. I. Djami, "Prehistoric Cultural Characteristics of the Planting System of the Dani Society in the Baliem Valley," J. Archaeological Research in Papua and West Papua, vol. 1, no. 2, pp. 69-82. 2017.

[25] J. P. Hutajulu, "Analysis of the Role of Women in Agriculture in Rasau Jaya District, Kuburaya Regency,” J. Social Economic of Agriculture, vol. 4, no. 1, pp. 83-90. 2015. 